\title{
STABILIZED ACTUATION OF A NOVEL NiTi SHAPE-MEMORY-ALLOY-ACTUATED FLEXIBLE STRUCTURE UNDER THERMAL LOADING
}

\author{
STABILIZIRAN ODZIV NOVE NiTi ZLITINE Z OBLIKOVNIM \\ SPOMINOM - ODZIV FLEKSIBILNE STRUKTURE NA TERMIČNO \\ OBREMENITEV
}

\author{
Savas Dilibal \\ Istanbul Gedik University, Faculty of Engineering, Mechatronics Engineering Department, Cumhuriyet Mh, Ilkbahar Sk. Yakacik Kartal, \\ 34987 Istanbul, Turkey \\ savas.dilibal@gedik.edu.tr
}

Prejem rokopisa - received: 2018-03-12; sprejem za objavo - accepted for publication: 2018-04-16

doi:10.17222/mit.2018.042

\begin{abstract}
Shape-memory-alloy (SMA) actuated flexible structures are used in a variety of configurations in many aerospace, robotics and underwater applications. In this study, a pair of nickel-titanium (NiTi) shape-memory-alloy plates is embedded in a flexible structure. An antagonistic design with a plate geometry is selected for the NiTi SMA to achieve bidirectional flexibility. A three-point-bending test is conducted to reveal the bending strength of the NiTi plates in the martensite and austenite phases. The antagonistic NiTi SMA plates are geometrically adapted and embedded into the flexible structure, which is fabricated through additive manufacturing using thermoplastic-polyurethane (TPU) flexible filament. The stabilized actuation stages of the antagonistic NiTi SMA plates embedded in the flexible structure are examined through observation of an extended number of thermal cycles. A comparison is made by applying two different electrical-current values with a regulated high-current DC power supply. A cycling profile with a maximum, bidirectional, stabilized actuation stroke of $52 \mathrm{~mm}$ is obtained through 100 heating/cooling cycles for the NiTi SMA-plate-actuated flexible structure. The effects of the high and low heating/cooling cyclic periods on the stabilized actuation stroke are also investigated.

Keywords: shape-memory alloy, nickel titanium, thermal loading, cyclic loading
\end{abstract}

Zlitine z oblikovnim spominom (SMA; angl.: Shape Memory Alloys) se kot odzivne fleksibilne strukture (aktuatorji) uporabljajo na različnih področjih: v letalstvu, robotiki in podvodnih aplikacijah. Avtor v članku predstavlja študijo para nikelj-titanovih plošč (NiTi) z oblikovnim spominom, vgrajenih v fleksibilno strukturo. Izbrali so antagonističen dizajn geometrije NiTi SMA plošč, da bi dosegli dvosmerno fleksibilnost. Izvedli so tritočkovni upogibni preizkus, da bi ugotovili upogibno trdnost martenzitne in austenitne faze NiTi plošč. NiTi SMA plošči so pritrdili in vgradili v fleksibilno strukturo, ki so jo izdelali s pomočjo dodajalnega postopka (AD; angl.: additive manufacturing). Pri tem so uporabili fleksibilna vlakna iz termoplastičnega poliuretana (TPU). Stabilna stanja odziva antagonistične fleksibilne NiTi SMA strukture so opazovali pri podaljšanem številu termičnih ciklov. Izdelali so primerjavo pri dveh različnih jakostih toka z reguliranim napajanjem z visokim enosmernim električnim tokom. Ciklični profil z maksimalno dvosmerno stabiliziranim aktuacijskim sunkom velikosti $52 \mathrm{~mm}$ so dosegli po stotih ogrevalno-ohlajevalnih ciklih. Avtorji so prav tako raziskovali vpliv dolžine ogrevalno-ohlajevalne dobe na stabiliziran odzivni sunek.

Ključne besede: zlitine z oblikovnim spominom, nikelj-titan, termične obremenitve, ciklično obremenjevanje

\section{INTRODUCTION}

Nickel-titanium shape-memory alloys are among the most widely used functional materials due to their outstanding shape memory and superelastic characteristics. ${ }^{1}$ They reshape the designs and structural concepts of many engineering systems, such as biomedical instruments, ${ }^{2}$ bio-inspired robots ${ }^{3}$ and aerospace structures. ${ }^{4-5}$ Particularly, NiTi SMA-actuated assembly systems are significant candidates to be used as elements embedded in flexible structures ${ }^{6}$ due to their high power/weight ratio and compact housing volume. However, the stabilized response of an assembled system is required to be permanently used together with a consistent stroke or strength.

There are many competing methods for achieving a stable mechanical ${ }^{7}$ or thermal ${ }^{8}$ cyclic stroke. A combina- tion of proper processing, structure and thermomechanical properties should be selected to achieve a repeatable functional performance of a NiTi SMA-based structure. The selected combination of these components determines the performance characteristics of the structure. Considering the processing methods, the chemical composition, the manufacturing technique and the heat treatment are the main parameters that affect the structure, the thermomechanical properties and, finally, the cyclic performance of an SMA-based actuator. The shape-memory effect and superelasticity are the two notable thermomechanical properties of the SMA materials. While the thermally induced martensitic transformation (TIMT) generates the shape-memory effect under isobaric conditions, the stress-induced martensitic transformation (SIMT) reveals the superelastic property under isothermal conditions. In terms of microstructure, 
the shape-memory effect occurs with the reverse phase transformation from martensite to austenite. Self-accommodated martensite variants form through the TIMT. In contrast, favorably oriented martensite variants and further detwinning occur under mechanical loading during the SIMT. Upon unloading, the austenitic microstructure forms through reverse phase transformation. ${ }^{9}$

Most of the isothermal or isobaric experimental studies have focused on the feasibility of the linear or rotary actuation for single NiTi SMA wire ${ }^{10}$ or spring ${ }^{11}$ actuated structures. However, an antagonistically actuated SMA-based mechanism provides a larger actuation stroke with higher degrees of freedom compared to the single-SMA-element-actuated structures. ${ }^{12}$ An antagonistic configuration consists of two opposing SMA elements, producing two-way mechanical work in an efficient manner. Many researchers worked on the antagonistic characteristics of the NiTi SMA, combining the shape memory and the superelastic responses using a wire, spring or plate. Sofla et al. ${ }^{13}$ studied on the antagonistic SMA wires based structural morphing mechanism for the twisting segments of the wing. Williams and Elahinia ${ }^{14}$ utilized a pair of antagonistic wires actuating the mechanism to replace the electrical motor-driven actuator in an automobile side mirror. A flap wing actuated by antagonistic NiTi SMA wires was examined by Senthilkumar ${ }^{15}$ concentrating on the pulling force of the pair of the SMA wires. Recently, the thermomechanical response of the antagonistic NiTi SMA-based actuation has been studied using pairs of SMA wires, ${ }^{14,16-17}$ springs $^{18}$ or plates. ${ }^{2,19}$ Attempts have also been made to obtain a large stroke from SMA springs using a novel spring configuration. ${ }^{20}$

The NiTi SMA-based structures provide different benefits, such as self-healing, ${ }^{21}$ self-sensing ${ }^{22-23}$ and damping. ${ }^{24}$ Attention must be paid to the stabilized response of the NiTi SMAs embedded in the structures under an extended number of thermal cycles. In this study, a novel flexible structure was developed using a couple of embedded, antagonistic NiTi SMA plates. The combination of processing-structure thermomechanical

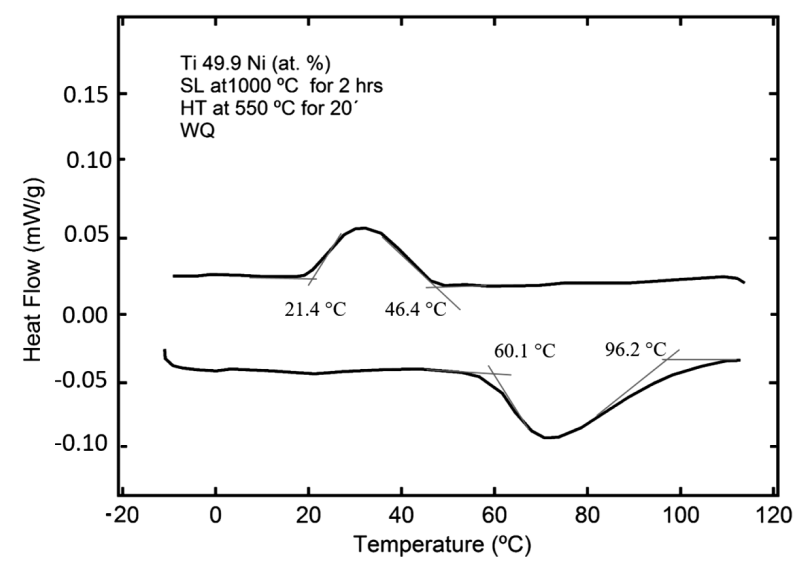

Figure 1: DSC results for the NiTi SMA plates properties were selected for the NiTi elements. To reveal the stabilized performance of the proposed NiTi SMA flexible structure, a prototype was manufactured and a special experimental set-up was established. The stabilized repetitive actuation stroke of the structure was investigated through 100 heating/cooling cycles under water condition.

\section{EXPERIMENTAL PART}

The polycrystalline martensitic NiTi SMA plates with a thickness of $1 \mathrm{~mm}$, produced by vacuum-induction casting and cold rolling were purchased from Memry (Weil am Rhein, Germany). The chemical compositions of NiTi $\left(x_{\mathrm{Ti}}=49.9 \%\right)$ were determined using an X-ray fluorescence (XRF) analysis of the NiTi SMA plate samples. Differential scanning calorimetry (DSC) was utilized to determine the reverse and forward martensitic-phase-transformation temperatures of the plate samples. The DSC analysis was conducted at heating and cooling rates of $15{ }^{\circ} \mathrm{C} \mathrm{min}-1$. The phase-transformation temperature of the NiTi SMA sample measured with DSC is shown in Figure 1. The martensite and austenite start/finish temperatures were found to be $M_{\mathrm{f}}=$ $21.4{ }^{\circ} \mathrm{C}, M_{\mathrm{s}}=46.4{ }^{\circ} \mathrm{C}, A_{\mathrm{s}}=60.1{ }^{\circ} \mathrm{C}$ and $A_{\mathrm{f}}=96.2{ }^{\circ} \mathrm{C}$.

Three-point-bending (TPB) tests were conducted using a universal testing machine with a $5-\mathrm{kN}$ load cell as shown in Figure 2. The NiTi SMA plate samples with dimension of $(1 \times 100 \times 20) \mathrm{mm}$ were used for the TPB tests at a $10 \mathrm{~mm} / \mathrm{min}$ loading rate. The first test set was carried out at a temperature of $21{ }^{\circ} \mathrm{C}$ and the NiTi SMA plate samples were in the martensitic state. Subsequently, the second test set was conducted with a DC power supply while the Joule heating of the NiTi SMA plate samples was above the $A_{\mathrm{f}}$ temperature, in a temperature range of $110-130{ }^{\circ} \mathrm{C}$. The three-point-bending test results for the NiTi SMA plates in fully martensitic and fully austenitic states are shown in Figure 2. The geometric design of the NiTi SMA plates was adapted to the design of the flexible mechanism. The NiTi SMA plates were cut using electrical discharge machining (EDM), following the final geometric design as shown in Figure

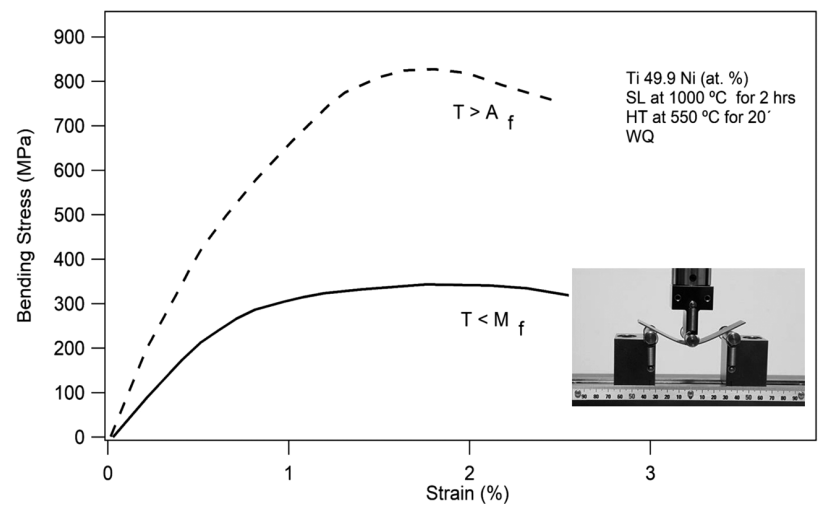

Figure 2: Three-point-bending test results for the NiTi plates in the martensitic and austenitic states 
a)

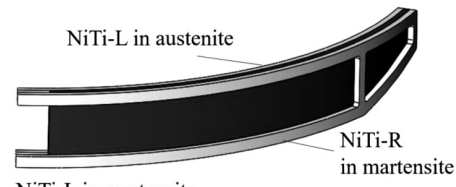

b)

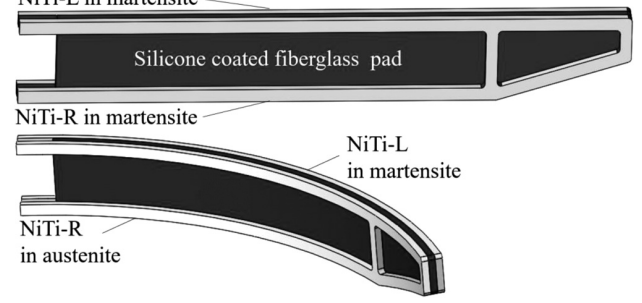

Figure 3: Design of the NiTi SMA plates: a) NiTi-L in the austenite phase / NiTi-R in the martensite phase, b) NiTi-L and NiTi-R in the martensite phase, c) NiTi-L in the martensite phase / NiTi-R in the austenite phase

3b. The final plate geometry was designed to increase the area where the moment can be applied to the flexible wing system. The EDM-processed NiTi SMA plates were heat treated at $1000{ }^{\circ} \mathrm{C}$ for $2 \mathrm{~h}$ in an argon atmosphere in a vacuum furnace. The desired curved shapes, depicted in Figures 3a and $\mathbf{3 c}$ as the austenitic form (NiTi-L and NiTi-R), were obtained with the heat treatment at $550{ }^{\circ} \mathrm{C}$ for $20 \mathrm{~min}$ and adapted to the designed aluminum mold.

After finishing the computer-aided design, the required flexible structure was built with additive manufacturing based on fused deposition modeling (FDM), using TPU filaments with a Shore A hardness of 85 . The assembly components used for fixing the flexible structure to the experimental set-up were made of ABS (acrylonitrile butadiene styrene) filaments. The shape of the antagonistic NiTi SMA plates was geometrically adapted and embedded into the flexible structure. The final geometry of the electrical-discharge-machined (EDM) NiTi SMA plates is shown in Figure 4. The EDM-processed NiTi SMA plates were fixed antagonistically into the flexible structure for the rotational actuation. A flexible silicone-coated fiberglass pad was assembled between the two NiTi SMA plates for electrical insulation.

The design and prototype of the antagonistic NiTi SMA embedded in the flexible structure are shown in

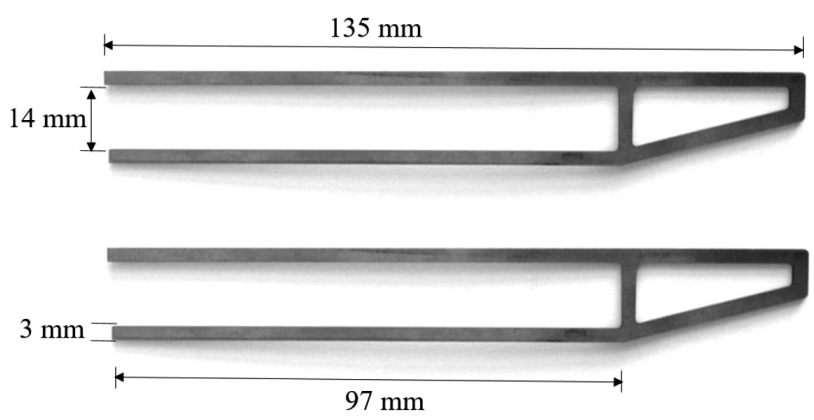

Figure 4: Final geometry of the electrical-discharge machined NiTi SMA plates a)
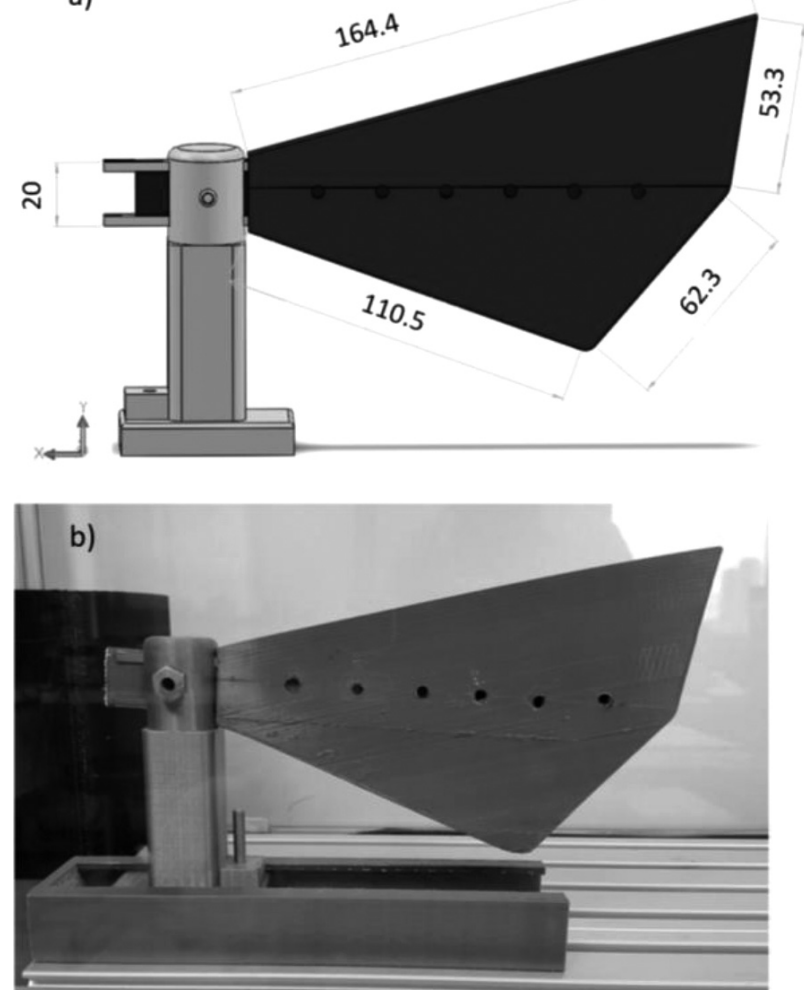

Figure 5: Design (a) and prototype (b) of the antagonistic NiTi SMA plates embedded in the flexible structure

Figure 5. Two different electrical-current levels of $60 \mathrm{~A}$ and 80 A were applied using a regulated high-current DC power supply. Two different heating/cooling cyclic periods were applied to observe the stabilized actuation. One is a high period; the other is a low period. In the high-period experiment, each of the antagonistic plates were heated alternately every 20 s. Specifically, each heating and cooling segment took place in $10 \mathrm{~s}$, in which the electrical current was applied for 2 s. In the lowperiod experiment, each antagonistic plate was heated alternately for $2 \mathrm{~s}$ during an 8 -second period. To examine the SMA-actuated flexible-structure characteristics under water conditions, an experimental set-up was established

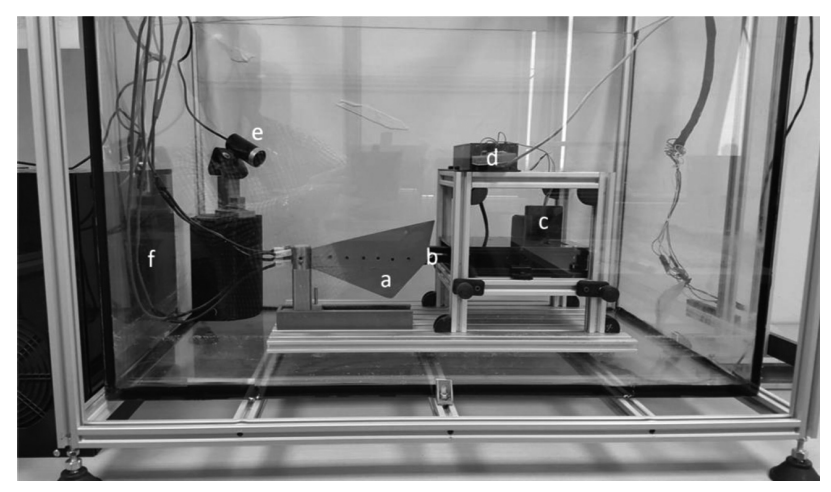

Figure 6: Experimental set-up for the SMA-actuated flexible structure; a) NiTi SMA-actuated structure, b) load cell, c) infrared sensor, d) microcontroller, e) camera, f) DC power supply 
as shown in Figure 8. An ABS fixture was fixed with screws onto an aluminum platform in a transparent water tank. An additively manufactured ABS joint was fixed to the ABS fixture. A silicone-coated fiberglass pad was placed between the NiTi SMA plates. The NiTi SMA plates were inserted inside the groove of the joint and fixed to the joint with two screws. The free side of the NiTi SMA plates was embedded into the additive-manufactured flexible enclosure. Heat-resistant electrical cables were connected to the legs of the NiTi SMA plates with heat-resistant electrical sockets.

A load cell was placed at the trajectory of the tip of the flexible structure to measure the force applied to the SMA-actuated flexible structure as shown in Figure 6. A compression spring with a stiffness of $0.65 \mathrm{Nmm}^{-1}$ was placed between the load cell and the blade tip. An infrared sensor was used to measure the actuation stroke at the tip of the flexible structure. Two thermocouples were placed on the surface of the NiTi SMA plates to measure the temperature change. Each thermal-cyclic experiment was conducted within the limits of $21-98{ }^{\circ} \mathrm{C}$ including 100 thermal cycles. A water pump was used to keep the water temperature constant by circulating the water in the water tank.

\section{RESULTS}

In order to obtain convenient Joule heating with a desired flexible-wing actuation, it is important to apply electrical currents to the antagonistic NiTi SMA plates without overheating them. Two different electricalcurrent values of $60 \mathrm{~A}$ and $80 \mathrm{~A}$ were used to observe the stabilized actuation during high and low heating/cooling cyclic periods. The displacement-versus-time results for each current level are shown in Figure 5 for the high heating/cooling cyclic period. It is observed that the electrical current of $80 \mathrm{~A}$ created the maximum stroke value during the thermal loading. As the obtained actuation stroke depends on the applied heat above the austenite finish temperature $\left(96.2^{\circ} \mathrm{C}\right)$, a larger stroke is

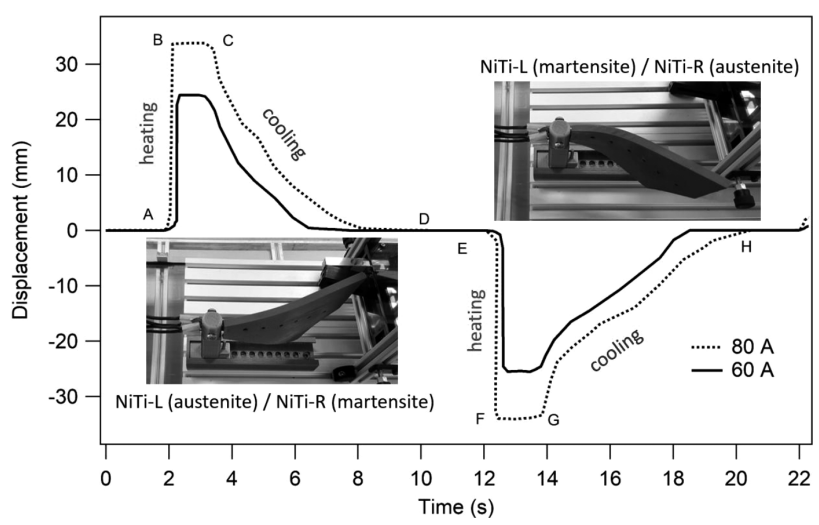

Figure 7: Antagonistic bidirectional displacement vs. time response of the flexible wing for the first thermal cycle with the electricalcurrent values of $60 \mathrm{~A}$ and $80 \mathrm{~A}$ observed at 80 A compared to $60 \mathrm{~A}$. Upon turning off the applied current, the temperature of the heated plate cools down to the martensitic phase. In this specific application, the martensite start temperature is $46.4{ }^{\circ} \mathrm{C}$ as shown in Figure 1. A combined plot of the applied bidirectional stroke versus time responses for the two different electrical-current values is depicted in Figure 8. When the specified current flows through the NiTi SMA plate at the left side of the flexible structure (NiTi-L), this structure heats up until reaching a fully austenitic state. This segment is depicted as A, B and C in Figure 7. After a 2-second time interval (A to $\mathrm{C}$ ), the cooling phase starts and continues between $\mathrm{C}, \mathrm{D}$ and $\mathrm{E}$. The martensitic-phase transformation is completed during this cooling period within $8 \mathrm{~s}$. Upon heating the NiTi SMA plate at the right side (NiTi-R), a similar actuation occurs following the path of E-F-G-H as shown in Figure 7.

The displacement and force results, obtained for each current value are shown in Figures 8 and 9. It is noteworthy that a gradual decrease occurred during the thermal cycling. The cyclic-experiment results revealed that the slope of the decrease rate was consequentially divided into different stages including the early-evolu-

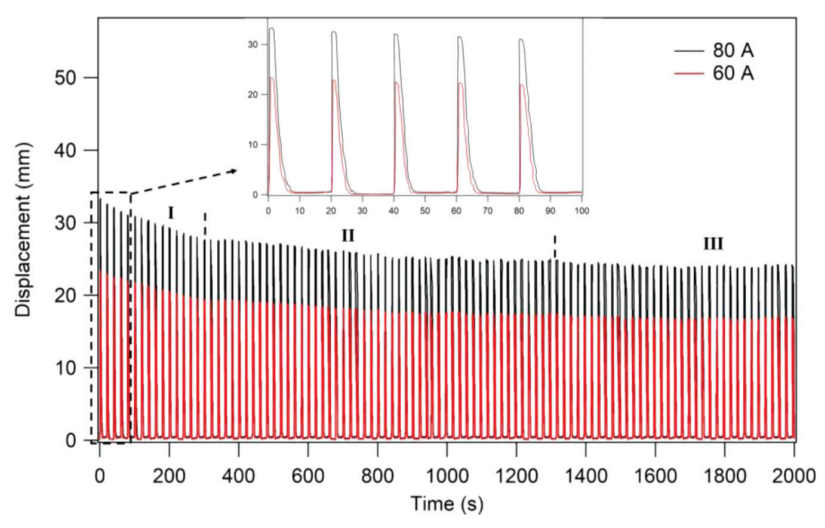

Figure 8: Displacement vs. time response of the embedded antagonistic NiTi SMA plate actuated flexible structure under 100 heating/ cooling thermal cycles

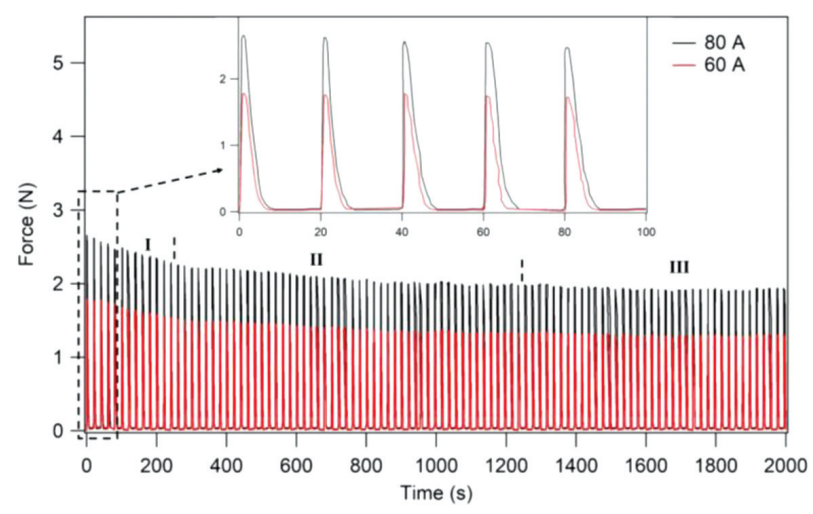

Figure 9: Force vs. time response of the antagonistic NiTi SMAactuated flexible structure under 100 heating/cooling thermal cycles 


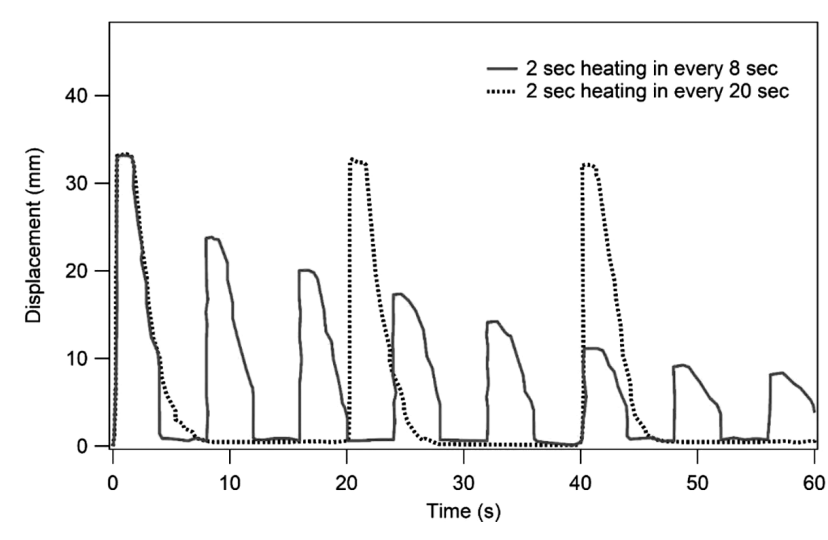

Figure 10: Comparison of the displacement vs. time responses of the antagonistic NiTi SMA-plate-actuated flexible structure with two different periods of heating/cooling thermal cycles

tion stage (I), transient stage (II, approach to the stabilization stage) and stabilization stage (III).

These stages were defined by three different slopes of the magnitudes of cyclic peaks for both the displacement and force data. We found that a notably large displacement occurred at 80 A compared to 60 A due to a faster Joule heating capacity. A stable actuation stroke of $26 \mathrm{~mm}$ was measured during the 100 heating/cooling cycles at $80 \mathrm{~A}$. A total bidirectional maximum actuation stroke of $52 \mathrm{~mm}$ was reached through the antagonistic actuation when the electrical-current flow was $80 \mathrm{~A}$. The early evolution occurred within the first 16 cycles as shown in Figure 9. Particularly, the displacement vs time plots for $80 \mathrm{~A}$ and $60 \mathrm{~A}$ start at $33 \mathrm{~mm}$ and $24 \mathrm{~mm}$, ending at $26 \mathrm{~mm}$ and $17 \mathrm{~mm}$. The cycles of the stages for $80 \mathrm{~A}$ and $60 \mathrm{~A}$ were 1-16 for the early evolution, 17-70 for the transient stage, and 71-100 for the stabilization stage.

Similar evolutionary characteristics were observed in the force vs time plots during the thermal cycling as shown in Figure 9. The transient stage started after 16 cycles and continued until the end of the $70^{\text {th }}$ cycle. Finally, the stabilization stage was reached at the $71^{\text {st }}$ cycle. Particularly, the force vs time plots for $80 \mathrm{~A}$ and 60 A start at $2.7 \mathrm{~N}$ and $1.7 \mathrm{~N}$, ending at $2.1 \mathrm{~N}$ and $1.4 \mathrm{~N}$.

A comparison was made between the actuation strokes obtained during high and low heating/cooling cyclic periods. The measured directional stroke decreased dramatically from $33 \mathrm{~mm}$ to $8 \mathrm{~mm}$ in the initial 8 cycles due to the low heating/cooling period (2-second heating in every 8-second period) as shown in Figure 10. The experimental results showed that a partial austenite/martensite transformation causes a fast degradation of the obtained stroke without reaching a proper stability. Contrary to the low heating/cooling period, the high heating/cooling period allows a stabilized actuation as shown in Figures 8 and 10.

\section{DISCUSSION}

The concept of an antagonistic NiTi SMA-actuated flexible structure is used to develop a compliant structure with a stabilized actuation. The geometrical shape of the antagonistic NiTi SMA plates is designed based on a flexible structure geometry. A systematic procedure is followed during the selection of the material required for the performance of the mechanism, considering the proper processing, structure and thermomechanical properties. To obtain the maximum stroke from the SMA embedded in the flexible structure, one of the antagonistic plates should be in the fully martensitic state, while the other plate transforms into the austenitic phase through Joule heating. There should be a synchronization of the phase transformation for both the NiTi-L and NiTi-R plates through cyclic Joule heating period. This synchronization covers the complete phase transformation. This procedure is crucial to prevent high degradation of the obtained stroke. Additionally, the bending stress in the martensite phase is lower than the bending stress in the austenite phase as shown in Figure 2. Thus, the heating/cooling thermal cyclic period of the antagonistic system should be designed according to these phenomena. When failing to obtain a fully martensitic phase during the cooling, a higher bending stress should be applied to bend the system in one direction. A comparison between the two different Joule heating periods clearly shows that a lack of sufficient water cooling greatly decreases the operational stroke of the flexible structure.

The cooling fluid and the antagonistic SMA configuration are two notable components, which accelerate the performance of the embedded-SMA-actuated structure. Typically, the response time of the SMA-actuated structure is fast upon heating. However, it takes too much time to cool down to the martensite phase, even with forced air convection. In recent studies, new cooling techniques have been investigated to increase the heattransfer rate, such as air-jet-impingement cooling ${ }^{25-26}$ and nanofluid cooling. ${ }^{27}$ The proposed flexible structure is bidirectionally actuated by a couple of antagonistic SMA plates through alternate Joule heating under water conditions. The holes on the flexible structure increase the cooling rate of the antagonistic NiTi SMA plates, providing the contact with the water. A total of $10 \mathrm{~s}$ is required for each heating/cooling cycle for the proposed antagonistic structure. To obtain the maximum stroke from the SMA embedded in the flexible structure, one of the antagonistic plates should be in the fully martensitic state, while the other plate transforms into the austenitic phase through Joule heating. We note that the gained bidirectional stroke decreases dramatically when the heating/cooling cycle is not selected in accordance with the complete phase transformation. The three-pointbending test reveals that the bending strength of the austenite phase is much higher than the bending stress of the martensite phase. This explains that one of the 
antagonistic plates needs a higher bending force to move the antagonistic NiTi SMA pair into one direction during Joule heating. Additionally, an early degradation of the gained stroke occurs.

Considering the design geometry, the antagonistic design can be selected in the forms of a wire, spring or plate configuration, depending on the application. However, the plate geometry of the antagonistic configuration provides various advantages in the design compared to the antagonistic wire design. The plate geometry can be transformed into different three-dimensional shapes. Moreover, it is easier to fix a plate component into any fixture than a wire counterpart. Additionally, an antagonistic pair of plates can apply the bending force in the opposite direction in a balanced manner compared to an antagonistic pair of wires.

The evolution of the thermal cyclic stabilization pattern should be taken into consideration to determine the long-term performance of the system. Any actuator structure needs to provide the required motion repeatability under service conditions. Thus, the major design requirement for a SMA-actuated flexible structure is a stabilized cyclic performance with a desired actuation stroke. When cyclic stability is reached, it can provide an enhanced sensorless position controllability of the flexible structure. An easy-to-use actuator control system is vital for an actuator. There has been a growing interest in the sensorless position control of the SMA-based actuator. Here, a stabilized large stroke obtained from an antagonistic SMA-actuated structure might be used for sensorless position control. Additionally, the excess number of the components, belonging to the actuator system affects the reliability of the system. To this end, the antagonistic actuator configuration presented in this study has the lowest number of components compared to the conventional actuator systems.

The experimental results show that the regulated high-current DC power supply with the maxi-mum current value of $80 \mathrm{~A}$ is sufficient for the designed flexible-wing actuator system. We note that a lithium-ion rechargeable battery can be used to obtain a mobile mechanism considering the necessary power supply for the Joule heating. The potential application fields for the developed SMA-actuated flexible structure can be the steering components of mini autonomous underwater vehicles (AUV) or remotely operated underwater vehicles (ROV), such as a fin, rudder, wing, etc. Moreover, the flexible trailing edge and chord-wise bending are mainly used in aeronautics researches..$^{5,13}$ The developed antagonistic NiTi SMA-plate-actuated flexible-wing system can be adapted to different aerospace applications, such as small unmanned aerial vehicles (UAV) or satellite systems. To develop an advanced SMA-actuated mechanism for the above systems, an interdisciplinary study is required, covering material, mechanical, electrical and control subsystems.

\section{CONCLUSIONS}

In this study, a novel antagonistic NiTi SMA-actuated flexible structure was designed, built and evaluated under thermal cycling. A stable and repeatable actuation stroke was obtained from specific antagonistic NiTi plates embedded in the structure. The experimental results unveiled that the cyclic heating/cooling period should be selected based on the complete phase transformation of the antagonistic NiTi SMA plates synchronized through Joule heating. This synchronization is crucial for preventing a notable cyclic degradation of the gained stroke from an antagonistic SMA plate configuration. Additionally, the cyclic stroke tended to stabilize through thermal cycling during three remarkable stabilizing stages. These are the early-evolution stage, transient stage and stabilization stage. The early evolution occurred in the initial 16 cycles. The transient stage took place between the $17^{\text {th }}$ and $70^{\text {th }}$ cycles. Finally, the stabilization stage was reached after the $71^{\text {st }}$ cycle. The largest stable bidirectional actuation stroke of 52 $\mathrm{mm}$ was obtained for this specific antagonistic design. In the future, the developed antagonistic NiTi SMA-actuated flexible structure will be used for a bio-inspired underwater application.

\section{REFERENCES}

${ }^{1}$ I. Chopra, J. Sirohi, Smart structures theory, Cambridge University Press, 2013

${ }^{2}$ J. M. Jani, M. Leary, A. Subic, M. A. Gibson, A review of shape memory alloy research, applications and opportunities, Materials \& Design, (2014) 56, 1078-1113, doi:10.1016/j.matdes.2013.11.084

${ }^{3}$ K. Hyung-Jung, S. Sung-Hyuk, A. Sung-Hoon, A turtle-like swimming robot using a smart soft composite (SSC) structure, Smart Materials and Structures, 22 (2013) 1, 1-11, doi:10.1088/0964-1726/ 22/1/014007

${ }^{4}$ F. T. Calkins, J. H. Mabe, Shape memory alloy based morphing aerostructures, ASME, J. Mech. Des., 132 (2010) 11, 1-7, doi:10.1115/1.4001119

${ }^{5}$ S. A. Meguid, Y. Su, Y. Wang, Complete morphing wing design using flexible-rib system, Int. J. Mech. Mater. Design, 13 (2017), 159-171, doi:10.1007/s10999-015-9323-0

${ }^{6}$ W. Kang, E. Kim, M. Jeong, I. Lee, S. Ahn, Morphing wing mechanism using an SMA wire actuator, International Journal of Aeronautical and Space Sciences, 13 (2012) 1, 58-63, doi:10.1088/0964-1726/23/7/074015

${ }^{7}$ S. Dilibal, R. F. Hamilton, A. Lanba, The effect of employed loading mode on the mechanical cyclic stabilization of NiTi shape memory alloys, Intermetallics, 89 (2017), 1-9, doi:10.1016/j.intermet.2017. 05.014

${ }^{8}$ M. F. X. Wagner, S. R. Dey, H. Gugel, J. Frenzel, Ch. Somsen, G. Eggeler, Effect of low-temperature precipitation on the transformation characteristics of Ni-rich NiTi shape memory alloys during thermal cycling, Intermetallics, 18 (2010) 6, 1172-1179, doi:10.1016/j.intermet.2010.02.048

${ }^{9} \mathrm{~S}$. Dilibal, Investigation of nucleation and growth of detwinning mechanism in martensitic single crystal NiTi using digital image correlation, Metallogr. Microstruct. Anal., 2 (2013), 242-248, doi:10.1007/s13632-013-0083-7

${ }^{10}$ W. Zhenlong, H. Guanrong, W. Yangwei, L. Jian, D. Wei, Embedded SMA wire actuated biomimetic fin: a module for biomimetic under- 
water propulsion, Smart Mater. Struct., 17 (2008) 2, 1-11, doi:10.1088/0964-1726/17/2/025039

${ }^{11}$ P. Sedlak, M. Frost, A. Kruisova, K. Hirmanova, L. Heller, P. Sittner, Simulations of mechanical response of superelastic NiTi helical spring and its relation to fatigue resistance, J. Mater. Eng. Perform. 23 (2014) 7, 2591-2598, doi:10.1007/ s11665-014-0906-y

${ }^{12} \mathrm{~T}$, Georges, V. Brailovski, P. Terriault, Characterization and design of antagonistic shape memory alloy actuators, Smart Mater. Struct., 21 (2012) 3, 1-8, doi:10.1088/0964-1726/21/3/035010

${ }^{13}$ A. Y. N. Sofla, S. A. Meguid, K. T. Tan, W. K. Yeo, Shape morphing of aircraft wing: Status and challenges, Materials and Design, 31 (2010), 1284-1292, doi:10.1016/j.matdes. 2009.09.011

${ }^{14}$ E. Williams, M. H. Elahinia, An automotive SMA mirror actuator: modeling design and experimental evaluation, J. Intell. Mater. Syst. Struct., 19 (2008), 1425-34, doi:10.1177/ 1045389X07087328

${ }^{15}$ M. Senthilkumar, Analysis of SMA actuated plain flap wing, Journal of Engineering Science and Technology Review, 5 (2012) 1, 39-43

${ }^{16} \mathrm{~S}$. Dilibal, E. Engeberg, Finger-like manipulator driven by antagonistic nickel-titanium shape memory alloy actuators, IEEE International Conference on Advanced Robotics, (2015), 152-157, doi:10.1109/ICAR.2015.7251448

${ }^{17} \mathrm{~W}$. Zhenlong, L. Jian, A flexible hingeless control surface inspired by aquatic animals, Journal of Bionic Engineering, 7 (2010) 4, 364-374, doi:10.1016/S1672-6529(10)60268-5

${ }^{18}$ S. Ameduri, A. Concilio, N. Favaloro, L. Pellone, A shape memory alloy application for compact unmanned aerial vehicles, Aerospace, 3 (2016) 2, 1-18, doi:10.3390/aerospace 3020016

${ }^{19}$ E. D. Engeberg, S. Dilibal, M. Vatani, J. W. Choi, J. Lavery, Anthropomorphic finger antagonistically actuated by SMA plates, Bioinspiration \& Biomimetics, 10 (2015) 5, 1-13, doi:10.1088/1748-3190/ $10 / 5 / 056002$

${ }^{20}$ S. W. Kim, J. G. Lee, S. An, M. Cho, K. J. Cho, A large-stroke shape memory alloy spring actuator using double-coil configuration, Smar Mater. Struct., 24 (2015), 1-21, doi:10.1088/0964-1726/24/9/095014
${ }^{21}$ P. Zhu, Z. Cui, M. S. Kesler, J. A. Newman, M. V. Manuel, M. Clar, L. Wrightd, C. Brinson, Characterization and modeling of threedimensional self-healing shape memory alloy-reinforced metalmatrix composites, Mechanics of Materials, 103 (2016), 1-10, doi:10.1016/j.mechmat.2016.09.005

${ }^{22}$ S. J. Furst, H. C. John, S. Seelecke, Stress, strain and resistance behavior of two opposing shape memory alloy actuator wires for resistance-based self-sensing applications, J. Intell. Mater. Syst. Struct., 24 (2013) 16, 1951-1968, doi:10.1177/1045389X13486715

${ }^{23}$ A. Sreekanth, T. Mathew, R. Vijayakumar, A novel model-based approach for resistance estimation using rise time and sensorless position control of sub-millimetre shape memory alloy helical spring actuator, J. Intell. Mater. Syst. Struct., (2017), 1-15, doi:10.1177/ 1045389X17730911

${ }^{24}$ E. Wanga, C. Guoa, P. Zhoua, C. Lina, X. Hanb, F. Jiang, Fabrication, mechanical properties and damping capacity of NiTi fiber-reinforced metal-intermetallic-laminate composite, Materials \& Design, 95 (2016), 446-454, doi:10.1016/j.matdes.2016.01.130

${ }^{25}$ M. Kilic, T. Calisir, S. Baskaya, Experimental and numerical investigation of vortex promoter effects on heat transfer from heated electronic components in a rectangular channel with an impinging jet, Heat Transfer Research, 48 (2017) 5, 435-463, doi:10.1615/ HeatTransRes.2016011959

${ }^{26}$ M. Kilic, T. Calisir, S. Baskaya, Experimental and numerical study of heat transfer from a heated flat plate in a rectangular channel with an impinging air jet, Journal of the Brazilian Society of Mechanical Sciences and Engineering, 1 (2017) 39, 329-344, doi:10.1007/ s40430-016-0521-y

${ }^{27}$ M. Kilic, H. M. Ali, Numerical investigation of combined effect of nanofluids and multiple impinging jets on heat transfer, Thermal Science, (2018), 1-12, doi:10.2298/TSCI171204094K 